INTRODUCTION TO CRIMINAL JUSTICE 



\section{INTRODUCTION TO}

\section{CRIMINAL JUSTICE}

A Sociological Perspective

EDITED BY CHARIS E. KUBRIN

AND THOMAS D. STUCKY

STANFORD SOCIAL SCIENCES

An Imprint of Stanford University Press

Stanford, California 
Stanford University Press

Stanford, California

(C) 2013 by the Board of Trustees of the Leland Stanford Junior University. All rights reserved.

No part of this book may be reproduced or transmitted in any form or by any means, electronic or mechanical, including photocopying and recording, or in any information storage or retrieval system without the prior written permission of Stanford University Press.

Printed in the United States of America on acid-free, archival-quality paper

Library of Congress Cataloging-in-Publication Data

Introduction to criminal justice (Stanford, Calif.)

Introduction to criminal justice : a sociological perspective / edited by Charis E. Kubrin and Thomas D. Stucky.

pages $\mathrm{cm}$

Includes bibliographical references and index.

ISBN 978-0-8047-6259-5 (cloth : alk. paper)-ISBN 978-0-8047-6260-1 (pbk. : alk. paper)

1. Criminal justice, Administration of-Social aspects-United States. I. Kubrin, Charis Elizabeth, editor of compilation. II. Stucky, Thomas Dain, editor of compilation. III. Title.

HV9950.I576 2013

364.973-dc23 